\title{
Femtomole per Liter per Second
}

National Cancer Institute

\section{Source}

National Cancer Institute. Femtomole per Liter per Second. NCI Thesaurus. Code

C122206.

A concentration unit equal to one femtomole of solute in one liter of solution per unit of time equal to one second. $(\mathrm{NCl})$ 